\title{
Towards identification of molecular mechanisms of short stature
}

\author{
Lindsey A Waldman and Dennis J Chia*
}

\begin{abstract}
Growth evaluations are among the most common referrals to pediatric endocrinologists. Although a number of pathologies, both primary endocrine and non-endocrine, can present with short stature, an estimated $80 \%$ of evaluations fail to identify a clear etiology, leaving a default designation of idiopathic short stature (ISS). As a group, several features among children with ISS are suggestive of pathophysiology of the GH-IGF-1 axis, including low serum levels of IGF-1 despite normal GH secretion. Candidate gene analysis of rare cases has demonstrated that severe mutations of genes of the GH-IGF-1 axis can present with a profound height phenotype, leading to speculation that a collection of mild mutations or polymorphisms of these genes can explain poor growth in a larger proportion of patients. Recent genome-wide association studies have identified $\sim 180$ genomic loci associated with height that together account for approximately $10 \%$ of height variation. With only modest representation of the GH-IGF-1 axis, there is little support for the long-held hypothesis that common genetic variants of the hormone pathway provide the molecular mechanism for poor growth in a substantial proportion of individuals. The height-associated common variants are not observed in the anticipated frequency in the shortest individuals, suggesting rare genetic factors with large effect are more plausible in this group. As we advance towards establishing a molecular mechanism for poor growth in a greater percentage of those currently labeled ISS, we highlight two strategies that will likely be offered with increasing frequency: (1) unbiased genetic technologies including array analysis for copy number variation and whole exome/genome sequencing and (2) epigenetic alterations of key genomic loci. Ultimately data from subsets with similar molecular etiologies may emerge that will allow tailored interventions to achieve the best clinical outcome.
\end{abstract}

Keywords: Short stature, Growth hormone, IGF-1, GWAS, Chromosomal microarray, Sequencing, Chromatin

\section{Introduction}

Poor growth is among the most common reasons for referral to pediatric endocrinology specialists. The evaluation begins with a detailed history and physical examination. Past medical records indicating the growth pattern in infancy and childhood are highly desirable to shape the context of the presentation. The birth history should address any known history of intrauterine growth retardation (IUGR) and whether birth parameters indicate small for gestational age (SGA), as approximately $10-15 \%$ of SGA infants fail to display appropriate catchup growth in the first years of life and do not reach an adult height in the normal range [1]. Poor weight gain in

\footnotetext{
* Correspondence: dennis.chia@mountsinai.org

Institutional addresses: Division of Pediatric Endocrinology \& Diabetes, Department of Pediatrics, Icahn School of Medicine at Mount Sinai, One Gustave L. Levy Place, New York, NY 10029, USA
}

excess of poor linear growth better fits considerations for failure to thrive and carries a largely distinct differential diagnosis. The physical examination may reveal clues to an underlying etiology, such as a goiter with hypothyroidism, and should include assessment for abnormal body proportions that may be indicative of a skeletal dysplasia.

In the absence of specific features identified in the history and physical, a laboratory evaluation that assesses for pathologies that characteristically lead to poor growth is typically initiated (Table 1 ). Bone age $\mathrm{x}$-rays can provide a framework for adult height prediction; however, they do not reliably distinguish between normal and pathologic growth patterns. Additional testing is guided by clinical suspicion and not typically performed in a screening matter. For example, growth failure accompanied by excessive weight gain prompts an 
Table 1 Etiologies for short stature and common screening tests

\begin{tabular}{|c|c|}
\hline Etiology & Screening tests \\
\hline \multicolumn{2}{|l|}{ Genetic short stature } \\
\hline $\begin{array}{l}\text { Chromosomal aneuploidy, including } \\
\text { Turner syndrome }\end{array}$ & Karyotype in girls \\
\hline \multicolumn{2}{|l|}{ Microdeletion or duplication } \\
\hline \multicolumn{2}{|l|}{ Single gene disorders } \\
\hline \multicolumn{2}{|l|}{ Polygenic } \\
\hline \multicolumn{2}{|l|}{$\begin{array}{l}\text { Constitutional delay of growth } \\
\text { and puberty }\end{array}$} \\
\hline \multicolumn{2}{|l|}{ Hormonal pathologies } \\
\hline Growth hormone deficiency & IGF-1, IGF BP-3 \\
\hline Hypothyroidism & Thyroid function tests \\
\hline \multicolumn{2}{|l|}{ Cushing syndrome } \\
\hline \multicolumn{2}{|l|}{ Systemic diseases } \\
\hline Inflammatory disease, e.g. IBD, JIA & erythrocyte sedimentation rate \\
\hline Celiac disease & tissue transglutaminase antibodies \\
\hline Renal disorders & electrolytes, creatinine \\
\hline Liver disorders & liver function tests \\
\hline Hematologic disorders & complete blood count \\
\hline \multicolumn{2}{|l|}{ Birth history of IUGR/SGA } \\
\hline Medications & \\
\hline
\end{tabular}

evaluation for Cushing syndrome, or characteristic facies or heart murmur may warrant an investigation for Noonan syndrome. Similarly, genetic testing for abnormalities of the SHOX gene is usually reserved for those with evidence of a skeletal dysplasia, most characteristically Madelung deformity, or a highly suggestive inheritance pattern [2].

\section{Investigations to identify an etiology for short stature are} frequently unrevealing

A review prepared by international growth experts estimated that approximately $80 \%$ of short children evaluated by pediatric endocrinologists do not have an identified etiology and are therefore classified as idiopathic short stature (ISS) [3]. A history of SGA is found in $\sim 15 \%$ of short children, thereby making it the single most common identified etiology, although it is perhaps better termed an association as the mechanisms for absence of catch up growth and persistent short stature in a small percentage of those with a history of SGA remain largely unknown. Data accumulated from multiple studies finds that only $\sim 5 \%$ of short children have a pathologic laboratory finding identified by routine screening [4-6]. Based on the low yield and costs of these screening tests, the rationale for routinely performing them in otherwise asymptomatic short children has been questioned [7].
While the term ISS is extensively used in the literature and is accepted clinically as an indication for the use of $\mathrm{GH}$ by the FDA, the concept has many limitations that detract from its utility. Although adult height is a classic continuous phenotype determined by the interaction of multiple genetic, epigenetic, and environmental factors, designating an etiology implies that there is a single root cause for short stature in any individual subject. This admittedly flawed assumption likely carries greater validity when reserved for those with a more severe phenotype, e.g. height $\mathrm{SDS}<-3$ or $<-4$, rather than those at the lower limit of the normal range, and we therefore strongly prefer restricting the term ISS for those with more profound short stature. ISS specifically does not exclude elements of familial short stature (FSS) and constitutional delay of growth and puberty (CDGP) [3], which have long been recognized as among the most common reasons for being short for age but are likewise difficult to classify as normal variants or pathologic in any individual. Twin studies have revealed the heritability of height to be in the $80-90 \%$ range [8], and calculating mid-parental height alone can explain $40 \%$ of variation in adult height [9]. The strong genetic component of height fuels aspirations to identify molecular mechanisms of short stature in individual patients, rather than simply label the cause as idiopathic.

\section{Interpretation of the GH-IGF-1 axis in ISS can be challenging}

The GH-IGF-1 axis is the most important hormonal axis governing growth, and therefore any evaluation of a child presenting with poor growth must include consideration for potential pathologies that impact $\mathrm{GH}$ and IGF-1 (Table 2) [10]. The challenge faced by pediatric endocrinologists arises from the interpretations of laboratory values of this axis, particularly given the

Table 2 GH Research Society Consensus Guidelines [10]*, criteria for investigations of the GH-IGF axis

\section{Criteria}

- Severe short stature, height $<-3$ SDS

- Height $<1.5$ SDS below midparental target height

- Height <-2 SDS AND height velocity <-1 SDS for chronological age for $>1$ year; decrease in height SDS of $>0.5$ SDS over 1 year (children $>2$ years)

- Height velocity $<-2$ SDS for $>1$ year, or height velocity $<-1.5$ SDS for 2 years

- Signs indicative of an intracranial lesion

- Signs of multiple pituitary hormone deficiency

- Neonatal signs and symptoms of GH deficiency

"endorsed by the Councils and Drug and Therapeutics Committees of the European Society for Pediatric Endocrinology and the (formerly Lawson Wilkins) Pediatric Endocrine Society, the Australasian Pediatric Endocrinology Group, the Japanese Society for Pediatric Endocrinology, and the Sociedad Latinoamericana de Endocrinologia Pediatrica. 
spectrum of ranges observed in the context of FSS and CDGP. As an illustration of the difficulties in interpreting the laboratory values, the ISS consensus statement concluded that GH status should not be considered strictly as GH deficient or GH sufficient, but rather a range of probabilities spanning $0-100 \%$ [11].

Serum IGF-1 is produced predominantly by the liver in response to $\mathrm{GH}$, and has good reproducibility when assayed in reference laboratories [12]. With few exceptions [13], an IGF-1 value that is in the upper half of normal range for age has high negative predictive value for GH deficiency [10]. IGF-1 values vary considerably in otherwise normal children due to several factors including age, pubertal stage, and nutritional status. As children presenting for growth evaluations commonly have delayed puberty (or delayed bone age findings in children of prepubertal age), it is not entirely surprising that IGF-1 levels are frequently low for chronologic age in children with ISS, with reports of IGF-1 values $<-2$ SDS for chronologic age ranging from $25-50 \%$ [14-16]. Short children with low IGF-1 levels most often proceed with stimulation testing using two provocative agents as the gold-standard assessment of $\mathrm{GH}$ secretion, with a peak GH of $<10 \mu \mathrm{g} / \mathrm{L}$ traditionally used as the cutoff to define GH deficiency [10]. Still, it is well acknowledged that GH stimulation testing is problematic [17]. There are no clear data to establish how a normal GH response is defined, and the distinction between isolated partial GH deficiency and ISS has been labeled "largely arbitrary" [11].

Pediatric endocrinologists have inherent biases in focusing on pathologies of the GH-IGF-1 axis to explain poor growth, and several patterns of the GH-IGF-1 axis in ISS evoke potential pathologies. The high prevalence of low IGF-1 levels in ISS has been discussed, and when coupled with normal stimulation testing can be termed primary IGF deficiency. GH doses necessary to achieve normalization of IGF-1 are higher (with a broad range) in ISS than GH deficiency $[18,19]$, consistent with partial GH resistance. Furthermore, the growth velocity in response to achieving a similar IGF-1 level is also less in ISS than GH deficiency [19], consistent with partial IGF resistance. Measurements of GH binding protein (GHBP), commonly considered a surrogate for $\mathrm{GH}$ receptor expression, are low in approximately $90 \%$ of children with ISS [20]. Despite these combined features, it is the rare subject in whom the laboratory findings and molecular genetic studies establish a defined pathological etiology of the GH-IGF-I axis, outside of GH deficiency.

\section{Single gene mutations of genes of the GH-IGF-1 axis can present with short stature}

Analogous to other hormone systems, defects in multiple steps of the GH-IGF-1 axis have long been hypothesized as mechanisms of pathophysiology (Figure 1). Laron first described a cohort of 3 children who clinically resembled those with GH deficiency but had elevated levels of GH by laboratory testing [21]. With the cloning of the gene for the $\mathrm{GH}$ receptor in 1987 [22], autosomal recessive inherited defects of GHR were demonstrated as the first molecular etiology for the syndrome of GH insensitivity [23]. Since then, single gene defects in IGF1, STAT5B, IGF1R, and IGFALS have been identified that include a phenotype of short stature [24-28]. Other characteristic features that distinguish these cases include prenatal growth failure, microcephaly, and developmental delay with both IGFI and IGFIR [24,26], sensorineural deafness with $I G F 1$ [24], and immunodeficiency with STAT5B [25].

While these case reports have been instrumental in shaping understanding of genes necessary for normal growth, they do not establish that defects of these genes play a role in the poor growth in a substantial proportion of short children in the general population. A review from 2011 listed the total number of cases in the literature to be less than 300 [28], and even experienced pediatric endocrinologists may only have directly cared for a handful of patients known to carry such mutations among the thousands they have evaluated in their careers. With mutations of the GHR, STAT5B, IGF1, and IGFALS genes, homozygosity (generally only observed with parental consanguinity or a highly inbred population) or compound heterozygosity is characteristically necessary for the phenotype, supporting the notion that these cases only arise rarely. Heterozygous carriers of a mutation are described to have mild short stature that is at the lower end of the spectrum of the normal range $[28,29]$, with one study of individuals with mutations of IGFALS indicating that a defective allele in the heterozygote state results in a loss of height of approximately 1.0 SDS [30]. In addition, two dominant-negative mutations of GHR have been described [31,32], and there have been recent reports of heterozygous mutations of IGF1 associated with short stature $[33,34]$. It should be noted that individuals identified with mutations of IGF1R usually carry only a single defective allele [26,28], consistent with mouse models in which homozygous knockouts of the gene do not have sustained viability [35]. Finally, heterozygous gain-of-function mutations of PTPN11, which encodes the protein phosphatase SHP-2, are one genetic etiology of Noonan syndrome that has been suggested to function in altering the GH-IGF-1 axis [36-38]; however, the data demonstrating a distinction with other genetic etiologies of Noonan syndrome is not entirely conclusive $[39,40]$.

Initial identification of individuals harboring these mutations understandably focused on those with a severe phenotype, whereas it has since been appreciated that there is a continuum of abnormalities with some relationship between genotype and phenotype. For example, 


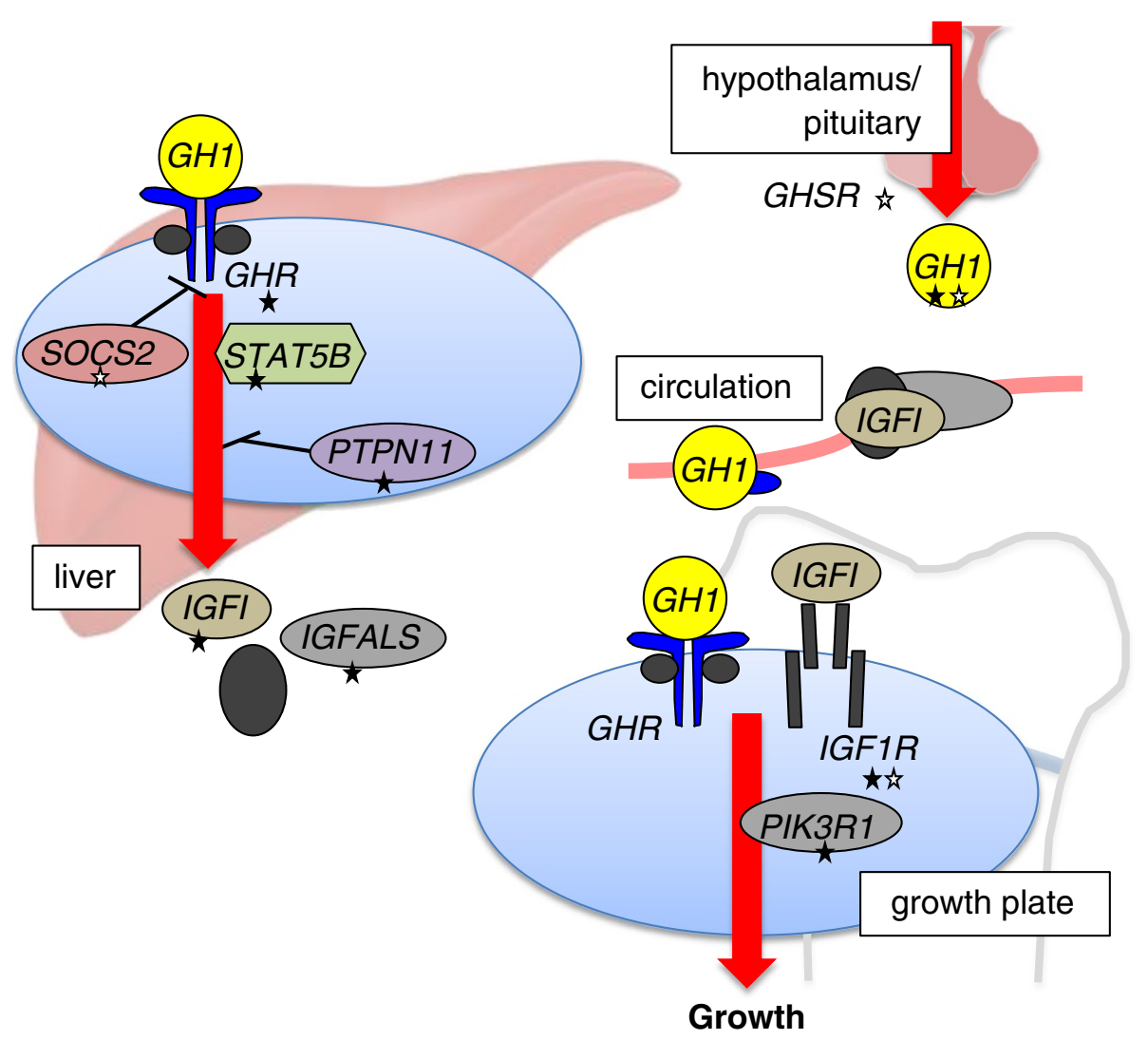

Figure 1 Described genetic defects of the GH-IGF-1 axis associated with growth. Multiple genes of the GH-IGF-1 axis have been identified that impact growth, in the setting of both case reports with severe mutations producing a profound phenotype (filled stars) and common variants that contribute a small effect in height GWA studies (clear stars). Note that there is modest overlap in the two sets of genes, with only GH1 and IGFIR implicated in both sets. The list of single gene defects functioning at the level of the hypothalamus and pituitary that give rise to GH deficiency has been abbreviated in the figure for clarity.

GHR missense and nonsense mutations produce a more severe growth phenotype than dominant-negative and intronic pseudoexon mutations [28]. Goddard and coworkers reported that 8 of 100 children with ISS carried variants in GHR, leading to the conclusion that mutations of GHR are a relatively common explanation for poor growth; however, the absence of significant functional data coupled with the failure of the variants to predictably track with the stature phenotype in family members, particularly in the setting that 7 of 8 were observed in the heterozygous state with one normal allele, raises considerable doubt to their conclusion that the identified variants contribute substantially to partial GH insensitivity [41,42]. A common variant of GHR that lacks exon 3 has also been investigated for an association with height, with most studies only finding an effect on growth velocity with exogenous $\mathrm{GH}$ administration $[43,44]$. The absence of strong data notwithstanding, there is seemingly a steadfast perception that common genetic defects of the GH-IGF-1 axis underlie a significant proportion of poor growth.

\section{Height GWA Studies have provided insights to the biology of height}

The common disease-common variant model holds that for complex polygenic traits and diseases, multiple common variants are present within the population that collectively confer an additive effect on the phenotype, and was first proposed to be applicable to height by the statistician and evolutionary geneticist Ronald Fisher nearly a century ago [45]. The most commonly assayed unit of genetic variation in the population is the single nucleotide polymorphism (SNP). Genome-wide association (GWA) studies seek to identify genetic loci that are associated with a particular phenotype in an unbiased manner by genotyping hundreds of thousands of SNPs simultaneously on a single microarray chip [46]. The investigator can then independently interrogate whether any individual SNP is associated with the phenotype of interest. Sample size in the neighborhood of tens of thousands is critical because multiple hypothesis testing necessitates stringent statistical thresholds to avoid falsepositive results, particularly given that common SNPs 
characteristically have a small effect size [47]. Current commonly used genome-scale microarrays sample common SNPs with minor allele frequencies primarily in the $10-50 \%$ range, and successive generations will likely capture SNPs with lower minor allele frequencies. It should also be noted that it is the rare exception in which the SNP itself has been shown to have a causal pathologic mechanism, but the genetic loci of the SNP can implicate biologically relevant genes and pathways.

Adult height with its Gaussian distribution in the population is particularly well-suited for GWA studies. Beginning with identification of a common SNP in the HMGA2 gene that conferred an estimated $0.4 \mathrm{~cm}$ increase in adult height in 2007 [48], the identification of genetic loci associated with height has been among the most successful of human GWA studies. Three independent groups reported their findings in 2008, escalating the total to over 40 loci associated with height [49-51]. More recently, the GIANT Consortium expanded their study to $>180$ thousand subjects, and reported at least 180 distinct loci that are associated with height [52]. The authors estimate that the SNP genotypes at these 180 loci explain approximately $10 \%$ of the variation of height in the population. It therefore follows that any single height allele explains only a small proportion of differences in height. Furthermore, identified SNPs with the greatest effect size are clustered with those with lower minor allele frequencies [53]. As 70$80 \%$ of heritability remains hidden, the predictive power from the current set of height GWA studies remains modest. On the contrary, these studies have been an unqualified success in providing biological insights to this field. The initial analyses by the GIANT Consortium described 21 of the loci to lie near OMIM skeletal or growth genes, with the majority of these known to be associated with skeletal dysplasias [52]. Taken further, Lui and co-workers used a combination of expression microarray of rodent growth plates and analyses of databases of human disease and mouse knockout phenotype to implicate 78 genes to growth plate function [54]. Many of the signaling pathways for these genes, for example PTHrP-IHH, BMP/TGF, and CNP, are not familiar to most clinical growth specialists, reinforcing the need for basic and clinical endocrinologists to maintain a continuous dialog. These genes may ultimately prove to function downstream of GH and IGF-1 at the growth plate, yet the mechanisms for convergence of these pathways have yet to be elucidated.

The list of genes identified by the height-GWA studies is also revealing in that it does not support many preconceived hypotheses on height. As discussed above, there is a rationale for the concept that common polymorphisms of genes of the GH-IGF-1 axis explain a significant proportion of the spectrum of height, and GH1,
GHSR, SOCS2, IGF1R, and IGF1BP2 are genes on the list that classically fit within this pathway (Figure 1). Yet conspicuous by their absences are the GHR and IGF1 genes that would be consistent with the hormonal phenotype of primary IGF deficiency and partial GH resistance. These negative findings are consistent with a previous smaller candidate SNP study that surveyed common SNPs in 8 selected genes of the GH-IGF-1 axis in 2200 short or tall subjects and also failed to identify any significant associations [55]. Interestingly, a study in dogs had found the IGF1 locus to be a major determinant in size, although clearly the selection of traits in breeding dogs and selective pressures during human evolution are difficult to equate [56]. As common variants near genes of the GH-IGF-1 axis constitute a small fraction of the total number of loci, which altogether explain only $10 \%$ of height heritability, it is safe to reject the long-held hypothesis that common polymorphisms of genes of the GH-IGF-1 axis play a substantial role in governing height.

Meanwhile, to address whether these common variants are impacting height in individuals with more extreme phenotypes, Chan et al. genotyped these SNPs in the 1214 subjects at the top and bottom 1.5 percentiles of two Scandinavian studies totaling over 78 thousand individuals [57]. While the pattern of alleles in the tall cohort matched the simulated proportions well, the heightassociated SNP variants did not perform as well in the short cohort. In particular, the observed pattern in the shortest subset $<0.25$ percentile was significantly different than the simulated pattern. Therefore in the extremely short cohort, the current data suggest that models of rare genetic or non-genetic factors are more applicable than contributions from multiple common variants.

\section{Unbiased genetic technologies can identify molecular defects in unanticipated genes}

In review, growth evaluations by pediatric endocrinologists have an inherent bias for ascertaining hormonal causes, particularly of the GH-IGF-1 axis, while the unbiased height GWA studies have revealed that known genes of the axis make up only a small fraction of the loci where common variants influence height. It therefore follows that rare single gene defects that present with poor growth will likely include a substantial proportion that lie in genes not commonly considered. Proportionally, common variants were exceedingly more prevalent in genes that function in the growth plate than those of the hormone axis [52,54], but it remains to be seen whether this will also be the case with rare variants. One would anticipate that in addition to overall short stature, single gene defects impacting the growth plate would present with features of skeletal dysplasia. 
Although abnormal body proportions can be evident on physical examination, many practitioners may find these differences difficult to recognize, as the phenotype may be subclinical. Therefore unbiased genome-wide technologies to identify rare defects should be considered as a potential tool to establish a molecular etiology for short stature.

Array-based technologies, including SNP genotyping arrays and comparative genomic hybridization, can detect copy number variations (CNV), either deletions or duplications, by comparing signal from a subject's DNA to a reference standard [58]. Briefly, the subject and reference DNA are independently labeled with flurorophores of different colors and allowed to competitively hybridize to sequences sampling the entire genome on the test array. Deviation from the expected 1:1 ratio of subject and reference DNA at a given genetic loci would be suggestive of a potential deletion or duplication. The technique is commonly described as a genome-wide fluourescence in situ hybridization (FISH), where one does not dictate the genetic loci to be studied, although notably a directed FISH currently maintains greater sensitivity for small CNVs than array studies.

Array studies are being used increasingly in clinical settings concomitant with their decreasing costs. They are largely considered a first-tier test for evaluation of children with congenital structural anomalies or altered neurocognitive development, including those with autism spectrum disorders. In the latter, CNVs are identified in the range of $12-14 \%$, providing a much higher diagnostic yield than standard karyotype [59]. Aside from case reports that detail identifying CNVs in individuals who had presented with poor growth, there have been a limited number of studies assessing CNVs on height. Dauber and colleagues investigated the impact of CNVs on growth by studying copy number burden in 4411 children with available height data who had a microarray study performed for other clinical indications [60]. They compared the CNV burden in the 415 subjects with height $<-2$ SDS, 196 with height $>+2$ SDS, and 3800 normal statured controls. Interestingly, they observed that the total CNV burden, both globally and restricted to genes, was significantly greater in the short, but not tall, children than the controls. Additional analysis revealed that deletions accounted for the difference in $\mathrm{CNV}$ burden in the short cohort, whereas there was no significant association with duplications. Given that common indications for attaining an array study are congenital anomalies and altered neurocognitive development, it is difficult to apply the findings of this study to a more general population.

Recently, the group of Zahnleiter et al. from Germany performed CNV analysis of 200 children with ISS (height $<-2$ SDS, average -2.75) and compared the results with 820 normal controls [61]. Even with stringent criteria for defining pathogenic CNVs (no overlap with CNVs of the control group, exclusion of strictly intronic or intergenic CNVs, either de novo or cosegregated with short stature if familial, and evidence in the literature for a growth phenotype at the locus), they identified a total of 10 deletions and 10 duplications in 20 families, ranging in size from $109 \mathrm{~kb}-14.2 \mathrm{Mb} .3$ of these CNVs spanned one of the 180 height-associated SNPs [52], and several others spanned SNPs that demonstrated a trend for association but failed to meet the statistical threshold for a genome-wide study. The yield of $10 \%$ in this study (20 pathogenic CNVs in 200 children) is quite similar to that for autism spectrum disorders. If other groups confirmed a diagnostic yield in this range, there would be a reasonable argument that array studies should also be considered for all children with ISS. Presently they are not performed as common practice, and no groups have recommended their implementation in the diagnostic algorithm for poor growth.

Case reports of individuals presenting with a profound growth phenotype and subsequently identified to carry a single gene defect by unbiased sequencing are likewise increasingly common. Whereas in the past, positional cloning requiring multiple affected and unaffected individuals within a family was the primary modality to identify genetic lesions leading to a characteristic phenotype, investigators can now employ next-generation sequencing that allows for interrogation of DNA mutations in the exome or genome of a single presenting individual. A cursory literature search of the past 12 months reveals the use of whole exome sequencing in reports of short stature in individuals harboring mutations of POC1A, NIN, CUL7, PIK3R1, KDM6A, and XYLT1 [62-69]. Notably, PIK3R1 encodes the p85a regulatory subunit of phosphatidylinositol 3 kinase, that is a key downstream signaling molecule of insulin and IGF-1 [70], although the mechanism leading to poor growth in these short individuals has yet to be fully determined. Furthermore, two groups have employed candidate gene sequencing by first enriching for genetic regions of interest by using pre-designed biotinylated cRNA baits prior to next-generation sequencing $[16,71]$. This technique should increase specificity that an identified variant impacts growth, but sacrifices the potential to identify causal lesions in unanticipated genetic loci. Interestingly, among 192 children with short stature, Wang et al. identified 3 cases with known variants of PTPN11 leading to undiagnosed Noonan syndrome and one probable pathogenic variant of IGF1R [71]. Similar to the array studies, the cost for performing next-generation sequencing is rapidly decreasing, with a $\$ 1000$ genome test seemingly on the horizon. The initial experience of the clinical sequencing center at Baylor has recently been 
reported by Yang and colleagues [72]. Of the initial 250 consecutive cases with broad clinical phenotypic presentations, 62 were determined to have a mutated allele that was highly likely to be causative, providing optimism that this non-biased approach has sufficient yield to be included in diagnostic algorithms.

Aside from costs, there remain several issues to be addressed as these unbiased genetic technologies are offered more commonly [73]. Discriminating whether an identified abnormality is disease-causing or a benign variant is a major obstacle that has been addressed by the American College of Medical Genetics and Genomics [74]. Although there are multiple databases available to help classify an identified abnormality, they are by no means comprehensive. Some strategies previously mentioned in evaluating CNVs are directly applicable to sequence variants, including absence in unaffected individuals and co-segregation with the phenotype in families. For sequence data confined to exons, one can assess whether the predicted change in the encoded protein would likely alter its function, however a direct assessment of function of the gene product is usually desired. Mutations in gene regulatory regions outside of exons could also theoretically impact gene expression and present with a clinical phenotype, but the level of experimental evidence to have confidence in causation would have to be compelling. As such, whole exome sequencing is currently more practical than whole genome sequencing in detecting potentially causative genetic abnormalities. Next, whether identifying a genetic etiology for poor growth will impact clinical care, as envisioned by the allure of personalized medicine, has yet to be established. One could reasonably argue that identification of the etiology could increase suspicion for other features known to be associated with defects of a particular gene function. Data from common subsets of individuals formerly falling under the umbrella of ISS may reveal patterns that establish new paradigms for management. For example, recognizing that the most common mutation causing Noonan syndrome results in disruption of $\mathrm{GH}$ signaling has led some investigators to hypothesize that recombinant IGF-1 will achieve a better outcome than GH [40]. Lastly, the unbiased studies will certainly reveal new findings of an individual that were not anticipated or of unclear significance. How to manage this genetic information going forward is an important topic of public health [74].

Clinical experience with these unbiased technologies is rapidly accumulating. The accessibility of $\mathrm{CNV}$ analysis and whole exome sequencing to pediatric endocrinologists will at least partly be dictated by how third-party payers authorize reimbursement for these tests. As data about the yield for identifying pathogenic variants is still emerging, we propose that these diagnostic studies be seriously considered in the clinical evaluation in the five scenarios where the perceived yield is highest (Table 3). Given the greater experience with the array-based studies and their lower cost, it seems prudent to begin with $\mathrm{CNV}$ analysis before proceeding with whole-exome sequencing. As the field becomes more experienced with the studies, we would anticipate that the criteria for their use would evolve.

\section{Epigenetic defects of key growth genes are a plausible mechanism for poor growth that is seldom evaluated} Mendelian genetic defects are the prototypical etiology that lead to changes in protein expression and function, but epigenetic changes represent another plausible mechanism that could give rise to changes in protein expression that manifest as a defined phenotype. Epigenetic changes are defined by 3 key characteristics, namely that they are stable, heritable and, and do not involve any changes of the DNA sequence [75]. Current research primarily focuses on two classes of epigenetic mechanisms, covalent modifications of histone tails and DNA methylation at cytosine residues in the context of cytosine followed by guanine (CpG). These influence gene expression at the level of chromatin, a term encompassing DNA with the associated histone proteins that allow its compaction. Characteristic patterns of chromatin at regulatory regions, e.g. promoters and enhancers, of actively transcribed genes include specific modifications of amino acid residues of histone tails and relative hypo-methylation at CpGs that occur together with increased accessibility and reduced compaction. Importantly, the chromatin landscape can be both geneand tissue-specific, thereby allowing epigenetic changes to alter the transcriptional competence of a given genetic locus (Figure 2).

Epigenetic mechanisms have been proposed to serve as the basis for the developmental origins of adult disease (often termed the Barker) hypothesis [76]. By this model, adaptive responses to environmental influences in early life alter long-term risks for disease. For example, a perceived nutrient-poor environment that gives rise to poor intrauterine growth and SGA results in maladaptive changes in a postnatal environment of nutrient

Table 3 Proposed criteria for unbiased genetic studies in ISS Criteria

- Severe short stature, height $<-3$ SDS for CNV, <-4 SDS for whole exome sequencing;

- Disproportionate short stature within family, height $<-2$ SDS from midparental target height;

- Height <-2 SDS AND major congenital abnormalities or neurocognitive disorder;

- Short stature segregating within the family in a dominant pattern;

- History of consanguinity 

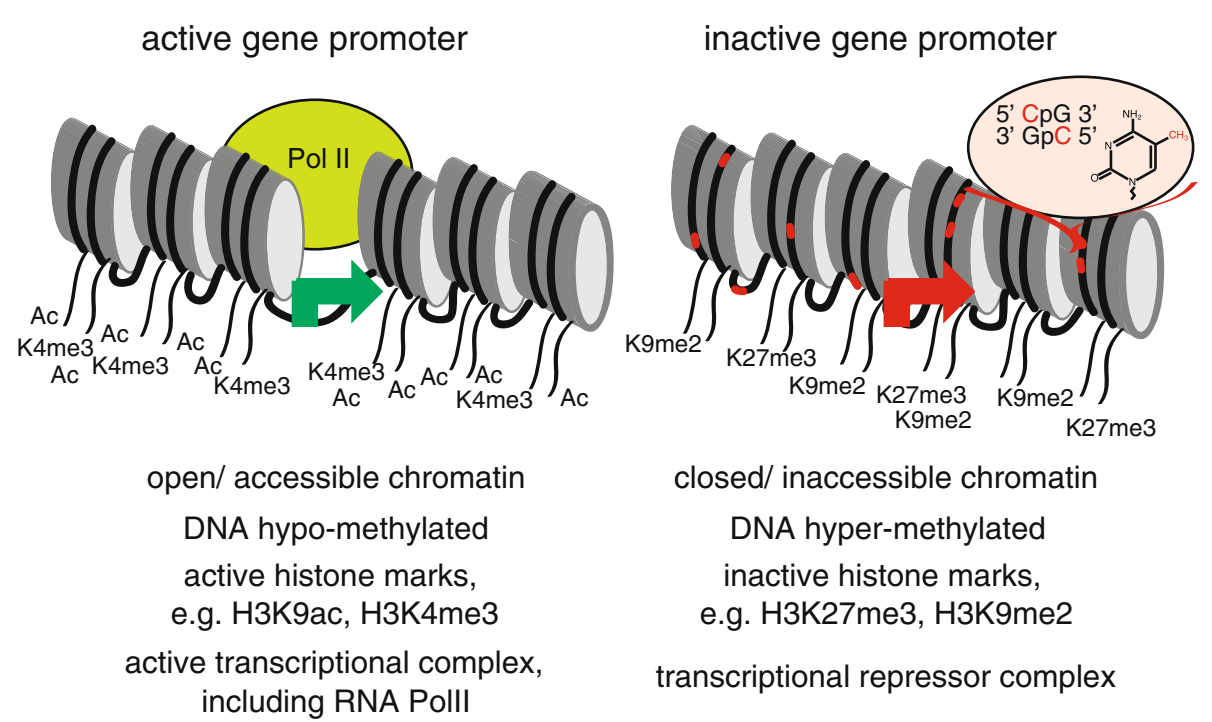

transcriptional repressor complex

Figure $\mathbf{2}$ The epigenetic context of gene regulatory elements can dictate gene expression. Active and inactive gene promoters are distinguished by several epigenetic features including chromatin accessibility, DNA methylation, covalent modification of histone tails, and the types of transcriptional proteins in the vicinity. These epigenetic features are frequently dichotomous in the same gene in different tissues, and also may be different in the same gene within the same tissue of different individuals as an explanation for differences in gene profiles. By definition, epigenetic changes do not involve any differences in the underlying DNA sequence.

excess, such that individuals are predisposed to features of the metabolic syndrome including Type 2 diabetes. In a rodent model of IUGR induced by maternal uterine artery ligation that predisposes to diabetes, Park and colleagues demonstrated reduced expression of the pancreatic transcription factor encoded by $P d x 1$ (homologous to IPF1 in humans) in islet cells, with evidence of epigenetic silencing of the gene locus [77]. Interestingly, treatment with a GLP-1 analog in the first week of life reverts the epigenetic landscape at the $P d x 1$ gene locus to normal and rescues the diabetes phenotype [78]. Epigenetic alterations in response to adverse intrauterine environments have been demonstrated in humans, for example in individuals prenatally exposed to the Dutch Hunger Winter of the Second World War [79]. Therefore there is a logical rationale that epigenetic alterations of key growth genes are a major mechanism for poor growth in IUGR/SGA.

In pediatric endocrinology, epigenetic mechanisms of disease pathogenesis are best illustrated with the complementary Beckwith-Wiedmann and Russell-Silver syndromes. It has recently been shown that changes in DNA methylation of differentially-methylated regions at the IGF2/H19 locus are the most common identifiable molecular etiologies for these two syndromes [80]. In simplistic terms, changes from the normal methylation pattern lead to overexpression of IGF2 in BeckwithWiedmann with overgrowth and underexpression of IGF2 in Russell-Silver with growth retardation. To reiterate, traditional DNA sequencing at the locus does not reveal any differences of the nucleotide sequence, and specific assessment of the DNA methylation pattern is necessary to identify the change.

By analogy, one could imagine that epigenetic changes leading to diminished transcriptional competence at GHR or IGF1 are a plausible mechanism for short stature in ISS, however there has yet to be any experimental evidence to support this hypothesis. Our laboratory has begun characterizing the chromatin landscape of the Igf1 gene in rodents using a variety of techniques [81,82]. We have recently shown that the promoter of the gene is accessible in multiple tissues, but that defined enhancers are only accessible in liver, where the gene is most highly expressed [83]. This finding implies that molecular studies to assess the chromatin landscape of the gene in accessible cells or tissues, commonly peripheral mononuclear blood cells, may not be a representative surrogate for that of liver, the tissue of interest. Investigators should bear consideration of this before ruling out epigenetic changes as a potential contributing mechanism. Whether epigenetic changes of growth genes will be shown to be a major contributing mechanism to poor growth in SGA, and more generally in ISS, in the coming years will be of great interest.

\section{Conclusions}

The majority of children who present for evaluation for short stature are not found to have an identified etiology and fall under the diagnosis of ISS. While rare singlegene defects impacting the GH-IGF-1 axis are well 
established as a mechanism for poor growth, recent studies refute the conventional hypothesis that common variants in these genes explain a significant proportion of short stature. Unbiased genetic technologies offer promise as tools to aid in diagnosis, but also introduce challenges that require careful consideration. Epigenetic alterations at specific genetic loci are another potential mechanism for poor growth that should be considered. As molecular etiologies for short stature are characterized more frequently in the coming years, the prospect of treatment plans individualized to the molecular etiology is intriguing.

\begin{abstract}
Abbreviations
CDGP: constitutional delay of growth and puberty; CNV: copy number variation; DNA: deoxyribonucleic acid; FDA: Federal Drug Administration; FISH: fluorescence in-situ hybridization; FSS: familial short stature; GH: growth hormone; GHBP: growth hormone binding protein; GWA: genome-wide association; IGF-1: insulin-like growth factor-1; ISS: idiopathic short stature; IUGR: intrauterine growth retardation; OMIM: Online Mendelian Inheritance of Man; RNA: ribonucleic acid; SDS: standard deviation score; SGA: small for gestational age; SNP: single nucleotide polymorphism; US: United States.
\end{abstract}

\section{Competing interests}

The authors declare that they have no competing interests.

\section{Authors' contributions}

LAW made contributions to the writing, reviewing, and editing of the manuscript. DJC made substantial contributions in the conception, planning, implementation, writing, reviewing, and editing of the manuscript, and gave final approval of the version to be published. All authors have read and reviewed the final manuscript.

\section{Authors' information}

LAW is a first-year fellow and DJC is an Assistant Professor in Pediatric Endocrinology \& Diabetes at the Icahn School of Medicine at Mount Sinai. The basic science interests of DJC include how epigenetics can influence gene expression in the IGF system.

\section{Acknowledgements}

DJC received supported from National Institutes of Health Grants K08 DK077897 and R03 DK092307. The NIH played no role in the writing or decision to submit the manuscript for publication. The authors thank Jennifer J. Chia for her critical appraisal and comments that contributed to the final version of the manuscript.

Received: 3 October 2013 Accepted: 8 November 2013

Published: 20 November 2013

\section{References}

1. Saenger P, Czernichow P, Hughes I, Reiter EO: Small for gestational age: short stature and beyond. Endocr Rev 2007, 28:219-251.

2. Rappold G, Blum WF, Shavrikova EP, Crowe BJ, Roeth R, Quigley CA, Ross JL, Niesler B: Genotypes and phenotypes in children with short stature: clinical indicators of SHOX haploinsufficiency. J Med Genet 2007, 44:306-313.

3. Cohen P, Rogol AD, Deal CL, Saenger P, Reiter EO, Ross JL, Chernausek SD, Savage MO, Wit JM: Consensus statement on the diagnosis and treatment of children with idiopathic short stature: a summary of the Growth Hormone Research Society, the Lawson Wilkins Pediatric Endocrine Society, and the European Society for Paediatric Endocrinology Workshop. J Clin Endocrinol Metab 2008, 93:4210-4217.

4. Voss LD, Mulligan J, Betts PR, Wilkin TJ: Poor growth in school entrants as an index of organic disease: the Wessex growth study. BMJ 1992, 305:1400-1402.

5. Ahmed ML, Allen AD, Sharma A, Macfarlane JA, Dunger DB: Evaluation of a district growth screening programme: the Oxford Growth Study. Arch Dis Child 1993, 69:361-365.
6. Lindsay R, Feldkamp M, Harris D, Robertson J, Rallison M: Utah Growth Study: growth standards and the prevalence of growth hormone deficiency. J Pediatr 1994, 125:29-35.

7. Sisley S, Trujillo MV, Khoury J, Backeljauw P: Low incidence of pathology detection and high cost of screening in the evaluation of asymptomatic short children. J Pediatr. in press.

8. Visscher PM, Medland SE, Ferreira MA, Morley Kl, Zhu G, Cornes BK, Montgomery GW, Marin NG: Assumption-free estimation of heritability from genome-wide identity-by-descent sharing between full siblings. PLoS Genet 2006, 2:e41.

9. Visscher PM, McEvoy B, Yang J: From Galton to GWAS: quantitative genetics of human height. Genet Res (Camb) 2010, 92:371-379.

10. GH Research Society: Consensus guidelines for the diagnosis and treatment of growth hormone (GH) deficiency in childhood and adolescence: summary statement of the GH Research Society. J Clin Endocrinol Metab 2000, 85:3990-3993.

11. Wit JM, Reiter EO, Ross $J$, Saenger PH, Savage MO, Rogol AD, Cohen P: Idiopathic short stature: management and growth hormone treatment. Growth Horm IGF Res 2008, 18:111-135.

12. Hilczer M, Smyczynska J, Stawerska R, Lewinski A: Stability of IGF-I concentration despite divergent results of repeated GH stimulating tests indicates poor reproducibility of test results. Endocr Regul 2006, 40:37-45.

13. Weinzimer SA, Homan SA, Ferry RJ, Moshang T: Serum IGF-I and IGFBP-3 concentrations do not accurately predict growth hormone deficiency in children with brain tumours. Clin Endocrinol (Oxf) 1999, 51:339-345.

14. Buckway CK, Guevara-Aguirre J, Pratt KL, Burren CP, Rosenfeld RG: The IGF-I generation test revisited: a marker of GH sensitivity. J Clin Endocrinol Metab 2001, 86:5176-5183.

15. Ranke MB: Defining insulin-like growth factor-I deficiency. Horm Res 2006, 65(Suppl 1):9-14.

16. Clayton $P$, Bonnemaire M, Dutailly P, Maisonobe P, Naudin L, Pham E, Zhang Z, Grupe A, Thiagalingam A, Denèfle P, EPIGROW Study Group: Characterizing short stature by insulin-like growth factor axis status and genetic associations: results from the prospective, cross-sectional, epidemiogenetic EPIGROW study. J Clin Endocrinol Metab 2013, 98:E1122-E1130.

17. Rosenfeld RG, Albertsson-Wikland K, Cassorla F, Frasier SD, Hasegawa Y, Hintz RL, Lafranchi S, Lippe B, Loriaux L, Melmed S: Diagnostic controversy: the diagnosis of childhood growth hormone deficiency revisited. J Clin Endocrinol Metab 1995, 80:1532-1540.

18. Attie KM, Carlsson LM, Rundle AC, Sherman BM: Evidence for partial growth hormone insensitivity among patients with idiopathic short stature. The National Cooperative Growth Study. J Pediatr 1995, 127:244-250.

19. Cohen P, Germak J, Rogol AD, Weng W, Kappelgaard AM, Rosenfeld RG, American Norditropin Study Group: Variable degree of growth hormone $(\mathrm{GH})$ and insulin-like growth factor (IGF) sensitivity in children with idiopathic short stature compared with GH-deficient patients: evidence from an IGF-based dosing study of short children. J Clin Endocrinol Metab 2010, 95:2089-2098

20. Carlsson LM, Attie KM, Compton PG, Vitangcol RV, Merimee TJ: Reduced concentration of serum growth hormone-binding protein in children with idiopathic short stature. National Cooperative Growth Study. J Clin Endocrinol Metab 1994, 78:1325-1330.

21. Laron Z, Pertzelan A, Mannheimer S: Genetic pituitary dwarfism with high serum concentation of growth hormone-a new inborn error of metabolism? Isr J Med Sci 1966, 2:152-155.

22. Leung DW, Spencer SA, Cachianes G, Hammonds RG, Collins C, Henzel WJ, Barnard R, Waters MJ, Wood Wl: Growth hormone receptor and serum binding protein: purification, cloning and expression. Nature 1987, 330:537-543.

23. Godowski PJ, Leung DW, Meacham LR, Galgani JP, Hellmiss R, Keret R, Rotwein PS, Parks JS, Laron Z, Wood Wl: Characterization of the human growth hormone receptor gene and demonstration of a partial gene deletion in two patients with Laron-type dwarfism. Proc Natl Acad Sci USA 1989, 86:8083-8087.

24. Woods KA, Camacho-Hübner C, Savage MO, Clark AJ: Intrauterine growth retardation and postnatal growth failure associated with deletion of the insulin-like growth factor I gene. N Engl J Med 1996, 335:1363-1367.

25. Kofoed EM, Hwa V, Little B, Woods KA, Buckway CK, Tsubaki J, Pratt KL, Bezrodnik L, Jasper H, Tepper A, Heinrich JJ, Rosenfeld RG: Growth hormone insensitivity associated with a STAT5b mutation. N Engl J Med 2003, 349:1139-1147. 
26. Abuzzahab MJ, Schneider A, Goddard A, Grigorescu F, Lautier C, Keller E, Kiess W, Klammt J, Kratzsch J, Osgood D, Pfäffle R, Raile K, Seidel B, Smith RJ, Chernausek SD, Intrauterine Growth Retardation (IUGR) Study Group: IGF-I receptor mutations resulting in intrauterine and postnatal growth retardation. N Engl J Med 2003, 349:2211-2222.

27. Domené HM, Bengolea SV, Martínez AS, Ropelato MG, Pennisi P, Scaglia P, Heinrich JJ, Jasper HG: Deficiency of the circulating insulin-like growth factor system associated with inactivation of the acid-labile subunit gene. N Engl J Med 2004, 350:570-577.

28. David A, Hwa V, Metherell LA, Netchine I, Camacho-Hübner C, Clark AJ, Rosenfeld RG, Savage MO: Evidence for a continuum of genetic, phenotypic, and biochemical abnormalities in children with growth hormone insensitivity. Endocr Rev 2011, 32:472-497.

29. Guevara-Aguirre J, Rosenbloom AL, Guevara-Aguirre M, Yariz K, Saavedra J, Baumbach L, Shuster J: Effects of heterozygosity for the E180 splice mutation causing growth hormone receptor deficiency in Ecuador on IGF-I, IGFBP-3, and stature. Growth Horm IGF Res 2007, 17:261-264.

30. Fofanova-Gambetti OV, Hwa V, Wit JM, Domene HM, Argente J, Bang P, Högler W, Kirsch S, Pihoker C, Chiu HK, Cohen L, Jacobsen C, Jasper HG, Haeusler G, Campos-Barros A, Gallego-Gómez E, Gracia-Bouthelier R, van Duyvenvoorde HA, Pozo J, Rosenfeld RG: Impact of heterozygosity for acid-labile subunit (IGFALS) gene mutations on stature: results from the international acid-labile subunit consortium. J Clin Endocrinol Metab 2010, 95:4184-4191.

31. Ayling RM, Ross R, Towner P, Von Laue S, Finidori J, Moutoussamy S, Buchanan CR, Clayton PE, Norman MR: A dominant-negative mutation of the growth hormone receptor causes familial short stature. Nat Genet 1997, 16:13-14

32. Iida K, Takahashi Y, Kaji H, Nose O, Okimura Y, Abe H, Chihara K: Growth hormone $(\mathrm{GH})$ insensitivity syndrome with high serum $\mathrm{GH}$-binding protein levels caused by a heterozygous splice site mutation of the $\mathrm{GH}$ receptor gene producing a lack of intracellular domain. J Clin Endocrinol Metab 1998, 83:531-537.

33. van Duyvenvoorde HA, van Setten PA, Walenkamp MJ, van Doorn J, Koenig J, Gauguin L, Oostdijk W, Ruivenkamp CA, Losekoot M, Wade JD, De Meyts P, Karperien M, Noordam C, Wit JM: Short stature associated with a novel heterozygous mutation in the insulin-like growth factor 1 gene. J Clin Endocrinol Metab 2010, 95:E363-E367.

34. Fuqua JS, Derr M, Rosenfeld RG, Hwa V: Identification of a novel heterozygous IGF1 splicing mutation in a large kindred with familial short stature. Horm Res Paediatr 2012, 78:59-66.

35. Liu JP, Baker J, Perkins AS, Robertson EJ, Efstratiadis A: Mice carrying null mutations of the genes encoding insulin-like growth factor I (Igf-1) and type 1 IGF receptor (Igf1r). Cell 1993, 75:59-72.

36. Tartaglia M, Mehler EL, Goldberg R, Zampino G, Brunner HG, Kremer H, van der Burgt I, Crosby AH, Ion A, Jeffery S, Kalidas K, Patton MA, Kucherlapati RS, Gelb BD: Mutations in PTPN11, encoding the protein tyrosine phosphatase SHP-2, cause Noonan syndrome. Nat Genet 2001, 29:465-468

37. Kim SO, Jiang J, Yi W, Feng GS, Frank SJ: Involvement of the Src homology 2-containing tyrosine phosphatase SHP-2 in growth hormone signaling. J Biol Chem 1998, 273:2344-2354.

38. Stofega MR, Herrington J, Billestrup N, Carter-Su C: Mutation of the SHP-2 binding site in growth hormone $(\mathrm{GH})$ receptor prolongs $\mathrm{GH}$-promoted tyrosyl phosphorylation of GH receptor, JAK2, and STAT5B. Mol Endocrinol 2000, 14:1338-1350.

39. Limal JM, Parfait B, Cabrol S, Bonnet D, Leheup B, Lyonnet S, Vldaud M, Le Bouc $Y$ : Noonan syndrome: relationships between genotype, growth, and growth factors. J Clin Endocrinol Metab 2006, 91:300-306.

40. Binder $\mathrm{G}$ : Response to growth hormone in short children with Noonan syndrome: correlation to genotype. Horm Res 2009, 72(Supp 2):52-56.

41. Goddard AD, Covello R, Luoh SM, Clackson T, Attie KM, Gesundheit N, Rundle AC, Wells JA, Carlsson LM: Mutations of the growth hormone receptor in children with idiopathic short stature. The Growth Hormone Insensitivity Study Group. N Engl J Med 1995, 333:1093-1098.

42. Goddard AD, Dowd P, Chernausek S, Geffner M, Gertner J, Hintz R, Hopwood N, Kaplan S, Plotnick L, Rogol A, Rosenfield R, Saenger P, Mauras N, Hershkopf R, Angulo M, Attie K: Partial growth-hormone insensitivity: the role of growth-hormone receptor mutations in idiopathic short stature. J Pediatr 1997, 131:S51-S55.
43. Dos Santos C, Essioux L, Teinturier C, Tauber M, Goffin V, Bougnères P: A common polymorphism of the growth hormone receptor is associated with increased responsiveness to growth hormone. Nat Genet 2004, 36:720-724.

44. Wassenaar MJ, Dekkers OM, Pereira AM, Wit JM, Smit JW, Biermasz NR, Romijn JA: Impact of the exon 3-deleted growth hormone (GH) receptor polymorphism on baseline height and the growth response to recombinant human GH therapy in GH-deficient (GHD) and non-GHD children with short stature: a systematic review and meta-analysis. J Clin Endocrinol Metab 2009, 94:3721-3730.

45. Fisher RA: The correlation between relatives on the supposition of Mendelian inheritance. Trans Roy Soc Edinb 1918, 52:399-413.

46. Altshuler D, Daly MJ, Lander ES: Genetic mapping in human disease. Science 2008, 322:881-888.

47. Dauber A, Hirschhorn JN: Genome-wide association studies in pediatric endocrinology. Horm Res Paediatr 2011, 75:322-328.

48. Weedon MN, Lettre G, Freathy RM, Lindgren CM, Voight BF, Perry JR, Elliott KS, Hackett R, Guiducci C, Shields B, Zeggini E, Lango H, Lyssenko V, Timpson NJ, Burtt NP, Rayner NW, Saxena R, Ardlie K, Tobias JH, Ness AR, Ring SM, Palmer CN, Morris AD, Peltonen L, Salomaa V, Davey Smith G, Groop LC, Hattersley AT, McCarthy MI, Hirschhorn JN, Frayling TM: A common variant of HMGA2 is associated with adult and childhood height in the general population. Nat Genet 2007, 39:1245-1250.

49. Weedon MN, Lango $H$, Lindgren CM, Wallace C, Evans DM, Mangino M, Freathy RM, Perry JR, Stevens S, Hall AS, Samani NJ, Shields B, Prokopenko I, Farrall M, Dominiczak A, Johnson T, Bergmann S, Beckmann JS, Vollenweider P, Waterworth DM, Mooser V, Palmer CN, Morris AD, Ouwehand WH, Zhao JH, Li S, Loos RJ, Barroso I, Deloukas P, Sandhu MS, et al: Genome-wide association analysis identifies 20 loci that influence adult height. Nat Genet 2008, 40:575-583.

50. Lettre G, Jackson AU, Gieger C, Schumacher FR, Berndt SI, Sanna S, Eyheramendy S, Voight BF, Butler JL, Guiducci C, Illig T, Hackett R, Heid IM, Jacobs KB, Lyssenko V, Uda M, Boehnke M, Chanock SJ, Groop LC, Hu FB, Isomaa B, Kraft P, Peltonen L, Salomaa V, Schlessinger D, Hunter DJ, Hayes RB, Abecasis GR, Wichmann HE, Mohlke KL, Hirschhorn JN: Identification of ten loci associated with height highlights new biological pathways in human growth. Nat Genet 2008, 40:584-591.

51. Gudbjartsson DF, Walters GB, Thorleifsson G, Stefansson H, Halldorsson BV, Zusmanovich P, Sulem P, Thorlacius S, Gylfason A, Steinberg S, Helgadottir A, Ingason A, Steinthorsdottir V, Olafsdottir EJ, Olafsdottir GH, Jonsson T, Borch-Johnsen K, Hansen T, Andersen G, Jorgensen T, Pedersen O, Aben KK, Witjes JA, Swinkels DW, den Heijer M, Franke B, Verbeek AL, Becker DM, Yanek LR, Becker LC, et al: Many sequence variants affecting diversity of adult human height. Nat Genet 2008, 40:609-615.

52. Lango Allen H, Estrada K, Lettre G, Berndt SI, Weedon MN, Rivadeneira F, Willer CJ, Jackson AU, Vedantam S, Raychaudhuri S, Ferreira T, Wood AR, Weyant RJ, Segrè AV, Speliotes EK, Wheeler E, Soranzo N, Park JH, Yang J, Gudbjartsson D, Heard-Costa NL, Randall JC, Qi L, Vernon Smith A, Mägi R, Pastinen T, Liang L, Heid IM, Luan J, Thorleifsson G, Winkler TW, et al: Hundreds of variants clustered in genomic loci and biological pathways affect human height. Nature 2010, 467:832-838.

53. Lettre $\mathrm{G}$ : Recent progress in the study of the genetics of height. Hum Genet 2011, 129:465-472.

54. Lui JC, Nilsson O, Chan Y, Palmer CD, Andrade AC, Hirschhorn JN, Baron J: Synthesizing genome-wide association studies and expression microarray reveals novel genes that act in the human growth plate to modulate height. Hum Mol Genet 2012, 21:5193-5201.

55. Lettre G, Butler $\mathrm{J}$, Ardlie KG, Hirschhorn JN: Common genetic variation in eight genes of the GH/IGF1 axis does not contribute to adult height variation. Hum Genet 2007, 122:129-139.

56. Sutter NB, Bustamante CD, Chase K, Gray MM, Zhao K, Zhu L, Padhukasahasram B, Karlins E, Davis S, Jones PG, Quignon P, Johnson GS, Parker HG, Fretwell N, Mosher DS, Lawler DF, Satyaraj E, Nordborg M, Lark KG, Wayne RK, Ostrander EA: A single IGF1 allele is a major determinant of small size in dogs. Science 2007, 316:112-115.

57. Chan Y, Holmen OL, Dauber A, Vatten L, Havulinna AS, Skorpen F, Kvaløy K, Silander K, Nguyen T, Willer C, Boehnke M, Perola M, Palotie A, Salomaa V, Hveem K, Frayling TM, Hirschhorn JN, Weedon MN: Common variants show predicted polygenic effects on height in the tails of the distribution, except in extremely short individuals. PLOS Genet 2011, 7:e1002439. 
58. Dhawan D, Padh H: Pharmacogenetics: technologies to detect copy number variations. Curr Opin Mol Ther 2009, 11:670-680.

59. Mefford HC, Batshaw ML, Hoffman EP: Genomics, intellectual disability, and autism. N Engl J Med 2012, 366:733-743.

60. Dauber A, Yu Y, Turchin MC, Chiang CW, Meng YA, Demerath EW, Patel SR, Rich SS, Rotter Jl, Schreiner PJ, Wilson JG, Shen Y, Wu BL, Hirschhorn JN: Genome-wide association of copy-number variation reveals an association between short stature and the presence of low-frequency genomic deletions. Am J Hum Genet 2011, 89:751-759.

61. Zahnleiter D, Uebe S, Ekici AB, Hoyer J, Wiesener A, Wieczorek D, Kunstmann E, Reis A, Doerr HG, Rauch A, Thiel CT: Rare copy number variants are a common cause of short stature. PLoS Genet 2013, 9:e1003365.

62. Sarig O, Nahum S, Rapaport D, Ishida-Yamamoto A, Fuchs-Telem D, Qiaoli L, Cohen-Katsenelson K, Spiegel R, Nousbeck J, Israeli S, Borochowitz ZU, Padalon-Brauch G, Uitto J, Horowitz M, Shalev S, Sprecher E: Short stature, onychodysplasia, facial dysmorphism, and hypotrichosis syndrome is caused by a POC1A mutation. Am J Hum Genet 2012, 91:337-342.

63. Dauber A, Lafranchi SH, Maliga Z, Lui JC, Moon JE, McDeed C, Henke K, Zonana J, Kingman GA, Pers TH, Baron J, Rosenfeld RG, Hirschhorn JN, Harris MP, Hwa V: Novel microcephalic primordial dwarfism disorder associated with variants in the centrosomal protein ninein. J Clin Endocrinol Metab 2012, 97:E2140-E2151.

64. Dauber A, Stoler J, Hechter E, Safer J, Hirschhorn JN: Whole exome sequencing reveals a novel mutation in CUL7 in a patient with an undiagnosed growth disorder. J Pediatr 2013, 162:202.e1-204.e1.

65. Thauvin-Robinet C, Auclair M, Duplomb L, Caron-Debarle M, Avila M, StOnge J, Le Merrer M, Le Luyer B, Héron D, Mathieu-Dramard M, Bitoun P, Petit JM, Odent S, Amiel J, Picot D, Carmignac V, Thevenon J, Callier P, Laville M, Reznik Y, Fagour C, Nunes ML, Capeau J, Lascols O, Huet F, Faivre L, Vigouroux C, Rivière JB: PIK3R1 mutations cause syndromic insulin resistance with lipoatrophy. Am J Hum Genet 2013, 93:141-149.

66. Chudasama KK, Winnay J, Johansson S, Claudi T, König R, Haldorsen I, Johansson B, Woo JR, Aarskog D, Sagen JV, Kahn CR, Molven A, Njølstad PR: SHORT syndrome with partial lipodystrophy due to impaired phosphatidylinositol 3 kinase signaling. Am J Hum Genet 2013, 93:150-157.

67. Dyment DA, Smith AC, Alcantara D, Schwartzentruber JA, Basel-Vanagaite L, Curry CJ, Temple IK, Reardon W, Mansour S, Haq MR, Gilbert R, Lehmann OJ, Vanstone MR, Beaulieu CL, Majewski J, Bulman DE, O'Driscoll M, Boycott KM, Innes AM: Mutations in PIK3R1 cause SHORT syndrome. Am J Hum Genet 2013, 93:158-166.

68. Miyake N, Koshimizu E, Okamoto N, Mizuno S, Ogata T, Nagai T, Kosho T, Ohashi H, Kato M, Sasaki G, Mabe H, Watanabe Y, Yoshino M, Matsuishi T, Takanashi J, Shotelersuk V, Tekin M, Ochi N, Kubota M, Ito N, Ihara K, Hara T, Tonoki H, Ohta T, Saito K, Matsuo M, Urano M, Enokizono T, Sato A, Tanaka $H$, et al: MLL2 and KDM6A mutations in patients with Kabuki syndrome. Am J Med Genet A 2013, 161:2234-2243.

69. Schreml J, Durmaz B, Cogulu O, Keupp K, Beleggia F, Pohl E, Milz E, Coker M, Ucar SK, Nürnberg G, Nürnberg P, Kuhn J, Ozkinay F: The missing "link": an autosomal recessive short stature syndrome caused by a hypofunctional XYLT1 mutation. Hum Genet 2013. in press.

70. Ueki K, Fruman DA, Brachmann SM, Tseng YH, Cantley LC, Kahn CR: Molecular balance between the regulatory and catalytic subunits of phosphoinositide 3-kinase regulates cell signaling and survival. Mol Cell Biol 2002, 22:965-977.

71. Wang SR, Carmichael H, Andrew SF, Miller TC, Moon JE, Derr MA, Hwa V, Hirschhorn JN, Dauber A: Large-scale pooled next-generation sequencing of 1077 genes to identify genetic causes of short stature. J Clin Endocrinol Metab 2013, 98:E1428-E1437.

72. Yang Y, Muzny DM, Reid JG, Bainbridge MN, Willis A, Ward PA, Braxton A, Beuten J, Xia F, Niu Z, Hardison M, Person R, Bekheirnia MR, Leduc MS, Kirby A, Pham P, Scull J, Wang M, Ding Y, Plon SE, Lupski JR, Beaudet AL, Gibbs RA, Eng CM: Clinical whole-exome sequencing for the diagnosis of mendelian disorders. N Engl J Med 2013, 369:1502-1511.

73. Dimmock D: Whole genome sequencing: a considered approach to clinical implementation. Curr Protoc Hum Genet 2013, 9(9):22

74. Richards CS, Bale S, Bellissimo DB, Das S, Grody WW, Hegde MR, Lyon E, Ward BE, Molecular Subcommittee of the ACMG Laboratory Quality Assurance Committee: ACMG recommendations for standards for interpretation and reporting of sequence variations: Revisions 2007. Genet Med 2008, 10:294-300.
75. Bonasio R, Tu S, Reinberg D: Molecular signals of epigenetic states. Science 2010, 330:612-616.

76. Hochberg Z, Feil R, Constancia M, Fraga M, Junien C, Carel JC, Boileau P, Le Bouc Y, Deal CL, Lillycrop K, Scharfmann R, Sheppard A, Skinner M, Szyf M, Waterland RA, Waxman DJ, Whitelaw E, Ong K, Albertsson-Wikland K: Child health, developmental plasticity, and epigenetic programming. Endocr Rev 2010, 32:159-224.

77. Park JH, Stoffers DA, Nicholls RD, Simmons RA: Development of type 2 diabetes following intrauterine growth retardation in rats is associated with progressive epigenetic silencing of Pdx1. J Clin Invest 2008, 118:2316-2324.

78. Pinney SE, Jaeckle Santos LJ, Han Y, Stoffers DA, Simmons RA: Exendin-4 increases histone acetylase activity and reverses epigenetic modifications that silence $\mathrm{Pdx} 1$ in the intrauterine growth retarded rat. Diabetologia 2011, 54:2606-2614.

79. Heijmans BT, Tobi EW, Stein AD, Putter H, Blauw GJ, Susser ES, Slagboom PE, Lumey LH: Persistent epigenetic differences associated with prenatal exposure to famine in humans. Proc Natl Acad Sci USA 2008, 105:1704617049.

80. Demars J, Le Bouc Y, El-Osta A, Gicquel C: Epigenetic and genetic mechanisms of abnormal $11 p 15$ genomic imprinting in silver-russell and beckwith-wiedemann syndromes. Curr Med Chem 2011, 18:1740-1750.

81. Chia DJ, Young JJ, Mertens AR, Rotwein P: Distinct alterations in chromatin organization of the two IGF-I promoters precede growth hormoneinduced activation of IGF-I gene transcription. Mol Endocrinol 2010, 24:779-789.

82. Chia DJ, Varco-Merth B, Rotwein P: Dispersed Chromosomal Stat5bbinding elements mediate growth hormone-activated insulin-like growth factor-I gene transcription. J Biol Chem 2010, 285:17636-17647.

83. Santhanam M, Chia DJ: Hepatic-specific accessibility of Igf1 gene enhancers is independent of growth hormone signaling. Mol Endocrinol 2013. ePub ahead of print.

doi:10.1186/1687-9856-2013-19

Cite this article as: Waldman and Chia: Towards identification of molecular mechanisms of short stature. International Journal of Pediatric Endocrinology 2013 2013:19.

\section{Submit your next manuscript to BioMed Central and take full advantage of:}

- Convenient online submission

- Thorough peer review

- No space constraints or color figure charges

- Immediate publication on acceptance

- Inclusion in PubMed, CAS, Scopus and Google Scholar

- Research which is freely available for redistribution 